\title{
Hydrogeology of Karang Mumus Watershed in Samarinda, East Kalimantan Province, Indonesia
}

\author{
Shalaho Dina Devy \\ Department of Mining Engineering, Universitas Mulawarman, Jl. Kuaro Kotak Pos 1068, \\ Samarinda 75119, Kalimantan Timur, Indonesia \\ Corresponding author (e-mail: shalaho.d2@ft.unmul.ac.id) \\ Received: 29 September 2017 / Accepted: 16 April 2018 / Published: 04 May 2018
}

\begin{abstract}
Samarinda is part of an anticlinorium, which is marked by the existence of many anticlines. In addition, various types of rock and aquifer can be found in the city due to the uniqueness of geological structure of the area. Nevertheless, the literature are lacking attention of hydrogeological condition of this area. This research aims to determine the hydrogeology of the Karang Mumus watershed, particularly in relation to its geology and land use conditions. The research uses an inductive method, with an analytical approach consisting of a study of the land use, hydrological conditions, geology, geomorphology and hydrogeology. The Karang Mumus watershed can be divided into three hydrogeological layers: (1) an aquitard layer, the top layer, which has a hydraulic conductivity of $4.3 \times 10^{-6} \mathrm{~m} / \mathrm{sec}$, and is dominated by siltstone; (2) an aquifer layer in the middle, with a hydraulic conductivity of $2.6 \times 10^{-4} \mathrm{~m} / \mathrm{sec}$, dominated by sand and sandstone; and (3) an aquiclude layer occupying the lower layer, with a hydraulic conductivity of $1.6 \times 10^{-11} \mathrm{~m} / \mathrm{sec}$, and which is dominated by claystone.
\end{abstract}

Keywords: aquifer, anticlinorium, Karang Mumus watershed, hydraulic conductivity.

\begin{abstract}
Abstrak. Samarinda merupakan wilayah yang berada di fisiografis Antiklinorium Samarinda yang ditandai dengan banyaknya lipatan-lipatan antiklin. Geomorfologi yang beragam dari rendah hingga perbukitan mengakibatkan Samarinda mempunyai karakteristik akuifer dan batas-batas hidrogeologis yang komplek. Namun demikian, hidrogeomofologi daerah ini masih sedikit dikaji. Tujuan dari penelitian ini yaitu mengetahui kondisi hidrogeologi daerah aliran sungai Karang Mumus yang sangat dipengaruhi oleh kondisi geologi, struktur geologi, dan tata guna lahan. Penelitian ini menerapkan metode induktif dengan pendekatan analitik yang meliputi kajian tata guna lahan, kondisi hidrologi. Berdasarkan hasil analisis, tipe hidrogeologi DAS Karang Mumus didominasi oleh (1) lapisan akuitar (konduktivitas hidraulika $4,3 \times 10^{-6} \mathrm{~m}$ / dek), (2) Lapisan akuifer (hidraulik hidraulik 2,6 $\times 10^{-4} \mathrm{~m} / \mathrm{dtk}$ ), dan (3) lapisan terakhir lapisan akuiklud (konduktivitas hidraulik 1,6 $\times 10^{-4} \mathrm{~m} /$ dek). Akuitar didominasi oleh batulanau, akuifer oleh pasir dan batupasir, serta akuiklud oleh batulempung.
\end{abstract}

Kata Kunci: Akuifer, Antiklinorium, DAS Karang Mumus, konduktivitas hidraulika.

\section{Introduction}

Hydrogeology is a branch of geology which studies the occurrence, movement, quality and quantity of water in the soil and rock of the earth's crust (commonly in aquifers). The study of hydrogeology is important both for scientific and practical aspects, since the availability of water is vital for human life. Where there is relation between changes in land use both in terms of quantity and quality are influenced by transitions in irrigation, industrialization, mining, and urbanisation (Cholil, 2004). Land use change is a major factor influencing catchment hydrology and groundwater resources. In assessing land use, the presence, distribution and type of vegetation play important roles in the estimation of water yield in a catchment area (Albhaisi et al., 2013). 
The impacts of land use change in the Karang Mumus watershed and subsurface conditions, influenced by geological and hydrogeological conditions, will affect groundwater recharge, as well as groundwater quantity and quality, and will directly impact on groundwater flow patterns. Physiographically, Samarinda is included in the Kutai Basin Zone (Van Bemmelen, 1949). Supriatna et al. (1995) state that the stratigraphy of the Kutai Basin is marked by several sedimentary rock formations with a distinctive order, and with a sedimentary environment from land to shallow sea. Laterally, the Kutai Basin is divided into three physiographic zones: first, the western Kutai Basin of the lowlands; second, the undulating mountains of the Samarinda Anticlinorium, located in the middle, which is a formation of tectonic processes that work with the direction of northwest-southeast running with the geological products of many folds; and third, the Mahakam delta. These condition form Samarinda with complex aquifer and hydrological condition.

Hydrological conditions are vital in the measurement of groundwater recharge and as a determinant in the quantification of groundwater. Prior to hydrogeological and groundwater analysis, it is important to determine recharge zone, aquifer, and hydrogeological boundary conditions. Moreover, surface water capacity is strongly affected by the characteristics of the watershed, land use, rainfall and the recharge zone. This zone is greatly influenced by the hydrological cycle (Asdak, 1985; Arsyad, 1989).

The understanding of the relationship between physiography, geology and hydrogeology is important, hence need comprehensive studies. Some geological studies exist within the study area (e.g. Adriyani, 2014; Cibaj et al., 2014; Nalendra Jati, 2014), but less description of the condition of hydrogeology and groundwater aspects. Based on this issues, this paper aims to describe the hydrological and hydrogeological conditions of the Karang Mumus watershed, based on inductive research with an analytic approach. The remainder of the paper is organized as follows: Section 2 provides an overview of the methodology; Section 3 presents and discusses the results; while the final section is the conclusion.

\section{Research Methods}

The study is inductive research with an analytical approach, focusing on hydrological and hydrogeological conditions. It is an in-depth study of aspects of hydrology, hydrogeology and land use. In addition to the analytical approach, quasi-experimental research was employed by considering the amount of data obtained from the field and in order to not merely combine the existing theories when drawing conclusions. The discussed research methods include geological, hydrological, land use, hydrogeological boundary, and geoelectrical study.

\subsection{Study Area}

The study site is located in the northern part of Samarinda, namely the Mahakam river, and is included in the Karang Mumus watershed, including four sub-districts in Samarinda and one sub-district in the Kutai Kartanegara regency, East Kalimantan province. Furthermore, the site comprises four formations of the Kutai Basin, namely those of Bebuluh, Pulau Balang, Balikpapan and Kampungbaru. These four formations compose the Samarinda Anticlinorium structure, which extends from north to south. However, due to changes in land use, such as for settlement, agriculture/plantations and mining, and anticipation of the impacts of hydrogeological and groundwater conditions, it is essential to undertake hydrological, geological, hydrogeological boundary and land use study. This research aims to assess the hydrogeological conditions of the Samarinda region, particularly the Karang Mumus watershed. 


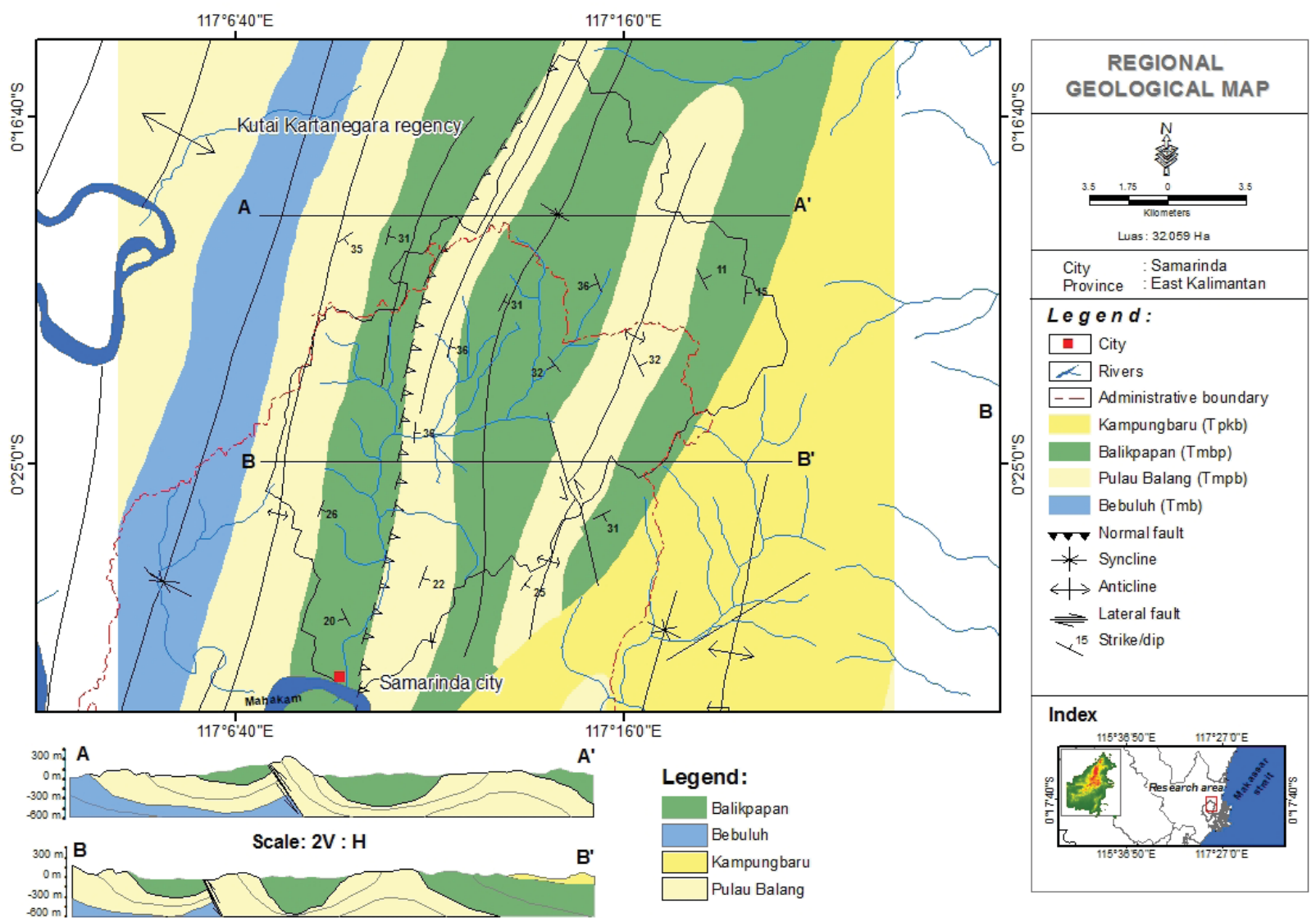

Figure 1. Regional geological map of Samarinda.

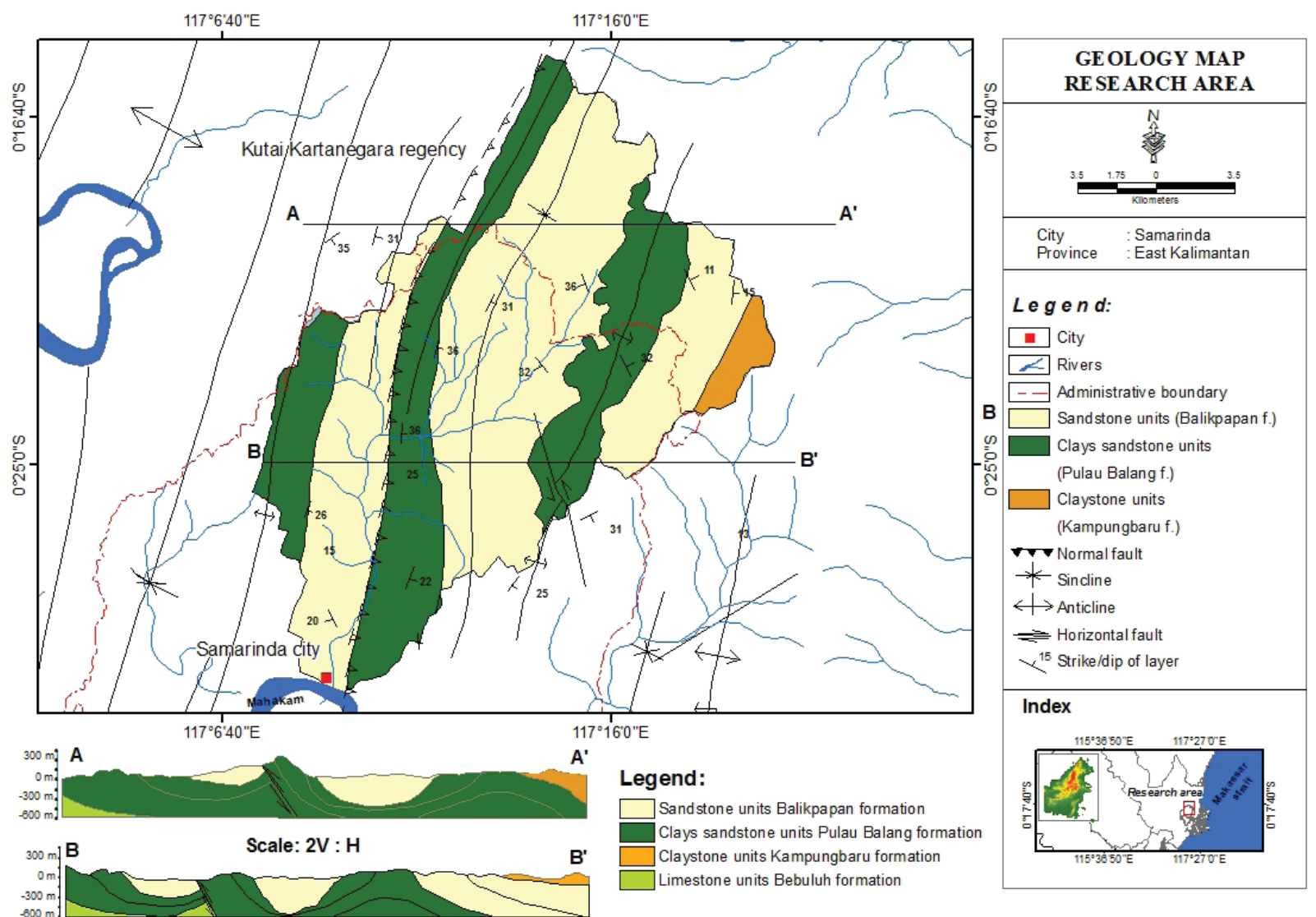

Figure 2. Location and geological map of study area. 


\subsection{Regional Geology}

Based on correlation between the regional geology and the results of surface and geoelectrical exploration, the stratigraphy of the study site, in order from the oldest to the youngest, is as follows: (1) the Bebuluh formation (Early-Late Miocene); (2) the Pulau Balang formation (Middle-Late Miocene); (3) the Balikpapan formation (Middle-Late Miocene); and (4) the Kampungbaru formation (MiddleLate Miocene). Of the four formations in the study site, the Balikpapan, Pulau Balang and Kampungbaru ones are relatively dominant. A description of the regional geology can be seen in Figure 1.

\subsection{Hydrology}

The determinant of the quantity of groundwater recharge is the intensity of rainfall (I). To measure this in a certain time of concentration, the Mononobe equation (Healy \& Cook, 2002; Lerner, 1990) was employed (see Equation 1). The time of concentration) from the rainfall is distributed uniformly over the watershed (see Equation 2 by Hammer \& Mac Kitchen [1981]). $\mathrm{T}_{\mathrm{c}}=$ time of concentration (min); L = length of the longest flow (m); V = velocity $\left(\mathrm{km} / \mathrm{hr}^{-1}\right)$ or $;$ and $\mathrm{H}=$ difference in elevation between upstream and simulated point in the watershed $(\mathrm{km})$.

$$
\begin{aligned}
& \mathrm{I}=\left(\frac{\mathrm{R}_{24}}{24}\right) \times\left(\frac{24}{\mathrm{~T}_{\mathrm{c}}}\right)^{2 / 3} \\
& \mathrm{~T}_{\mathrm{c}}=\frac{\mathrm{L}}{\mathrm{V}}
\end{aligned}
$$

The formula used to calculate the volume of runoff in accordance with the method developed by the US Department of Soil Conservation Service (SCS) is demonstrated in Equation 3 (Hammer \& Mac Kitchen, 1981). In this formula, $\mathrm{P}$ is precipitation and $\mathrm{S}$ is maximum potential retention, both in $\mathrm{mm}$. Maximum potential retention $(\mathrm{S}, \mathrm{mm})$ can be correlated with Equation 4. Meanwhile, to calculate the real evapotranspiration with the Thornthwaite method Equation 5 (Lerner, 1990). The Equation 5 expresses ET $\mathrm{r}_{\mathrm{r}}$
$=$ real evapotranspiration $(\mathrm{mm} / \mathrm{yr})$ and $\mathrm{T}_{\mathrm{m}}=$ annual average temperature $\left({ }^{\circ} \mathrm{C}\right)$. Meanwhile, the method used to measure groundwater recharge was that of Lerner (Healy \& Cook, 2002; Seiler \& Gat, 2007) as expressed in Equation 6 . Where $U$ = groundwater recharge $(\mathrm{mm} / \mathrm{yr}) ; \mathrm{P}=$ annual precipitation $(\mathrm{mm} / \mathrm{yr})$; $\mathrm{ET}_{\mathrm{r}}=$ real evapotranspiration $(\mathrm{mm} / \mathrm{yr})$; and Ro $=$ runoff due to soil permeability $(\mathrm{mm} / \mathrm{yr})$.

$Q=\frac{(P-0.2 S)^{2}}{(P+0.8 S)}$
$S=\frac{25400}{\mathrm{CN}}-254$

$\mathrm{ET}_{\mathrm{r}}=\frac{\mathrm{P}}{\sqrt{0.9+\frac{\mathrm{P}^{2}}{\left(300+25 . \mathrm{T}_{\mathrm{m}}+0.05 \cdot \mathrm{Tm}^{3}\right)^{2}}}}$

$\mathrm{U}=\mathrm{P}-\mathrm{ET}_{\mathrm{r}}-\mathrm{Ro}$

\subsection{Hydrogeological Boundaries}

The hydrogeological boundaries in the study site are determined by geomorphology and rock layers. Since the study site is in an anticline area, the hydrogeological boundaries include the groundwater divide boundary situated at the top/ridge of the anticline wing, as well as the internal and external boundaries of the groundwater face bounded by the river network. Meanwhile, the lower boundary layer, or non-flow area, is located in the limestone and claystone layer, as part of the Bebuluh formation. The hydrogeological boundaries are principal the typology of the aquifer system of the study site.

\subsection{Geoelectricity}

Geoelectrical estimation is intended to obtain an overview of subsurface layers of soil or rocks, as well as potential groundwater and minerals at a certain depth. The estimation is based on the fact that diverse materials have different resistivity when electrified; groundwater has lower resistance compared to mineral rocks. Several studies related to geoelectric estimation have investigated coal minerals (Ali et al., 2003) and groundwater exploration (Azhar \& Handayani, 2004). 


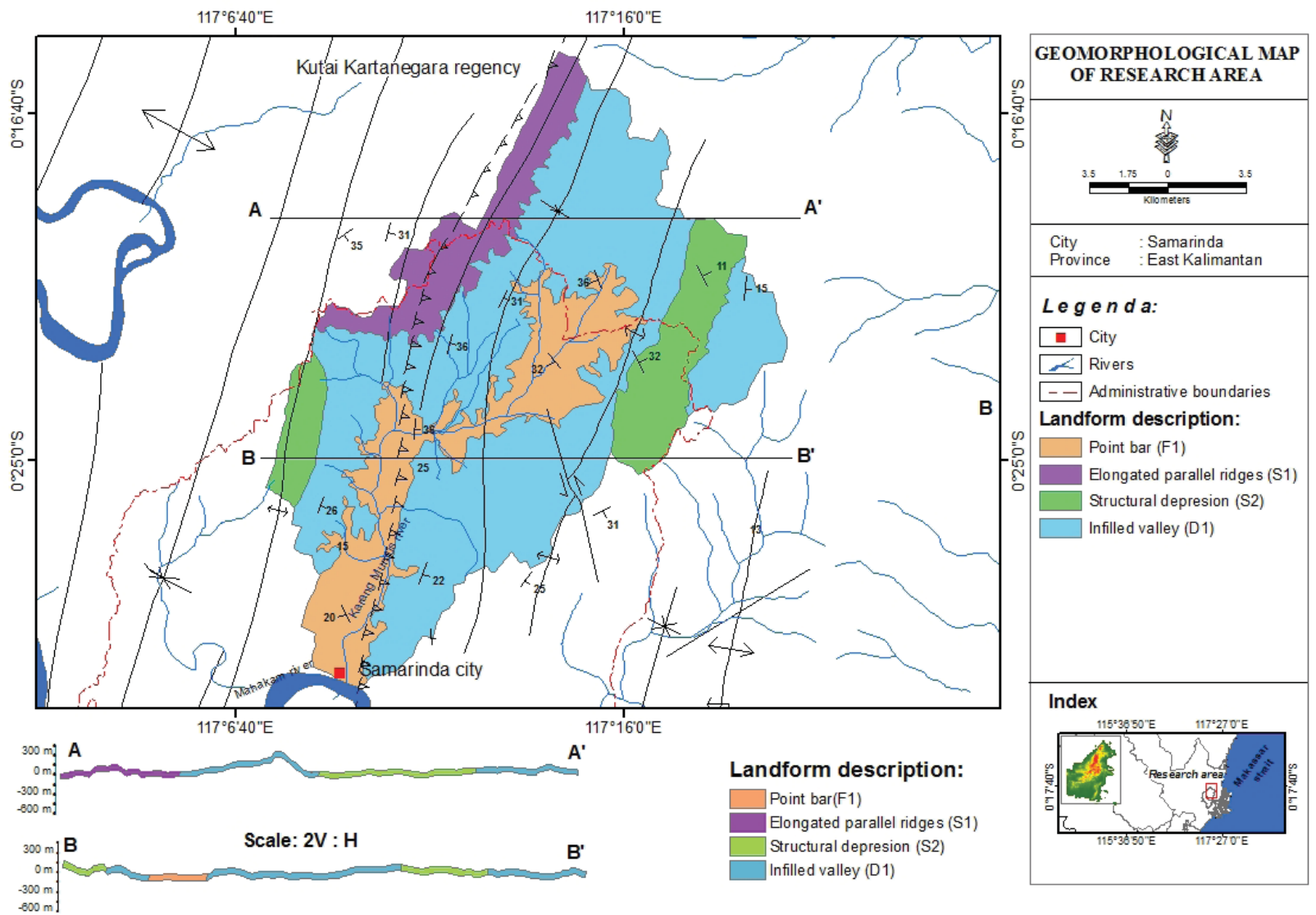

Figure 3. Location and geomorphological map of study area.

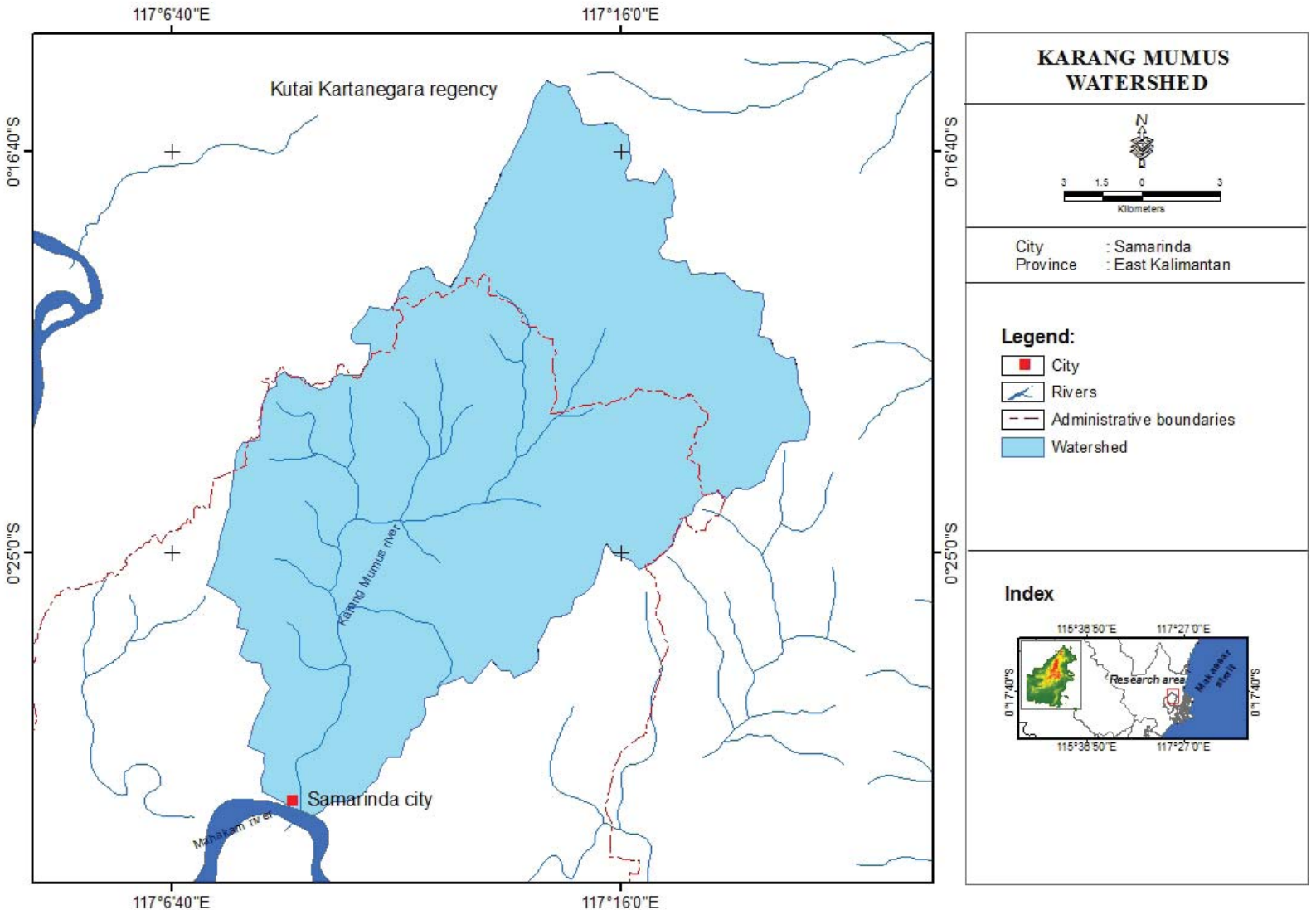

Figure 4. Location and watershed map of study area. 
The principle of this method is to measure resistivity by passing an electric current through rock or ground with a current electrode, which is received by a potential electrode. The potential difference between the two electrodes is measured with a voltmeter and based on the value, the resistivity of all types of rock is calculated by using Equation 7 (Telford et al., 1990). Where $\rho$ is resistivity; $2 \Pi$ = constant; $\mathrm{V}=$ potential difference; $\mathrm{I}=$ current; and $\mathrm{a}=$ distance of electrode.

$$
\rho=2 . \pi \cdot a \frac{V}{I}
$$

\section{Results and Discussion}

\subsection{Local Geology of Study Area}

Based on surface exploration and rock drilling log data, the four main formations are dominated by sandstone, claystone, clayey sandstone and limestone in various thicknesses. In addition, the units that dominate each formation are also identified. These rock units include limestone (Bebuluh formation), claystone (Pulau Balang formation), sandstone (Balikpapan formation), and clayey sandstone (Kampungbaru formation).

The geological structure of the study area is composed of anticlines and fault, affected by the physiography of the Samarinda Anticlinorium. There are several minor faults that lead to the intersection or disappearance of the bedding. The study site is situated in the center of the lateral axis of anticline structures that stretch diagonally from north to south. The strike direction of the anticline fold structure is $\mathrm{N} 8^{\circ}-12^{\circ} \mathrm{E}$, with a dip of $16^{\circ}-25^{\circ}$ at the north Furthermore, the other strike direction is $\mathrm{N}$ $184^{\circ} \mathrm{E}$ to $\mathrm{N} 197^{\circ} \mathrm{E}$, with a dip of $20^{\circ}-26^{\circ}$ at the south (see Figure 2).

Based on a geomorphological survey, the study site is dominated by eroded hills (S2) stretching from north to south, which are largely due to the conditions of the anticline structures eroded by exogenous forces. Fault scarps (S1), steep slopes formed by new faults with marked steep walls, are spread over the eastern part of the Karang Mumus watershed, with a small number in the western part.
Meanwhile, alluvial plains (F1), located on both sides of the Karang Mumus River in the upstream (northern) to downstream (southern) areas of the study site, flow into the Mahakam River in the north and serve as the boundary of the Karang Mumus watershed. A description of the study site geomorphology is given in Figure 3.

\subsection{Local Hydrology of Study Area}

Samarinda, in the northern part of the Mahakam River, is included in the Karang Mumus watershed, with a total area of 32,059 $\mathrm{km}^{2}$. In the watershed, the nearest rainfall station is that of Temindung. The hydrological boundaries of the Karang Mumus watershed were determined based on the SRTM map and subsequently interpreted with software to obtain a watershed map; the watershed is bounded by a ridge that extends from the northwest to the east and is bordered by the Mahakam River downstream. These boundaries are illustrated in Figure 4.

Groundwater computation was based on meteorological data, water conditions, topography, vegetation, and surface water flow patterns in the catchment area (Yangxiao \& Wenpeng, 2011). Furthermore, the catchment area was determined by the land use on the Karang Mumus watershed, particularly at the sub-watershed, being the target of the research. The recharge zone is also dependent on the type of surface lithology and aquifers on the surface. The land use area boundaries are illustrated in Figure 5, and a specific description is presented in Table 1.

Table 1. Area and land use of the research area in the Karang Mumus watershed.

\begin{tabular}{lcc}
\hline \multicolumn{1}{c}{ Land cover type } & Area $\%$ & Area $\mathbf{( k m}^{2} \mathbf{)}$ \\
\hline Forest & 16 & $5,129.4$ \\
Paddy Field & 2.8 & 897.7 \\
Crop plantation/dry & 35.1 & $11,252.7$ \\
land agriculture & & $4,071.5$ \\
Shrubs & 12.7 & $9,393.3$ \\
Settlement & 29.3 & $1,314.4$ \\
Mining area & 4.1 & $32,059.0$ \\
\hline Total & 100 & \\
\hline
\end{tabular}




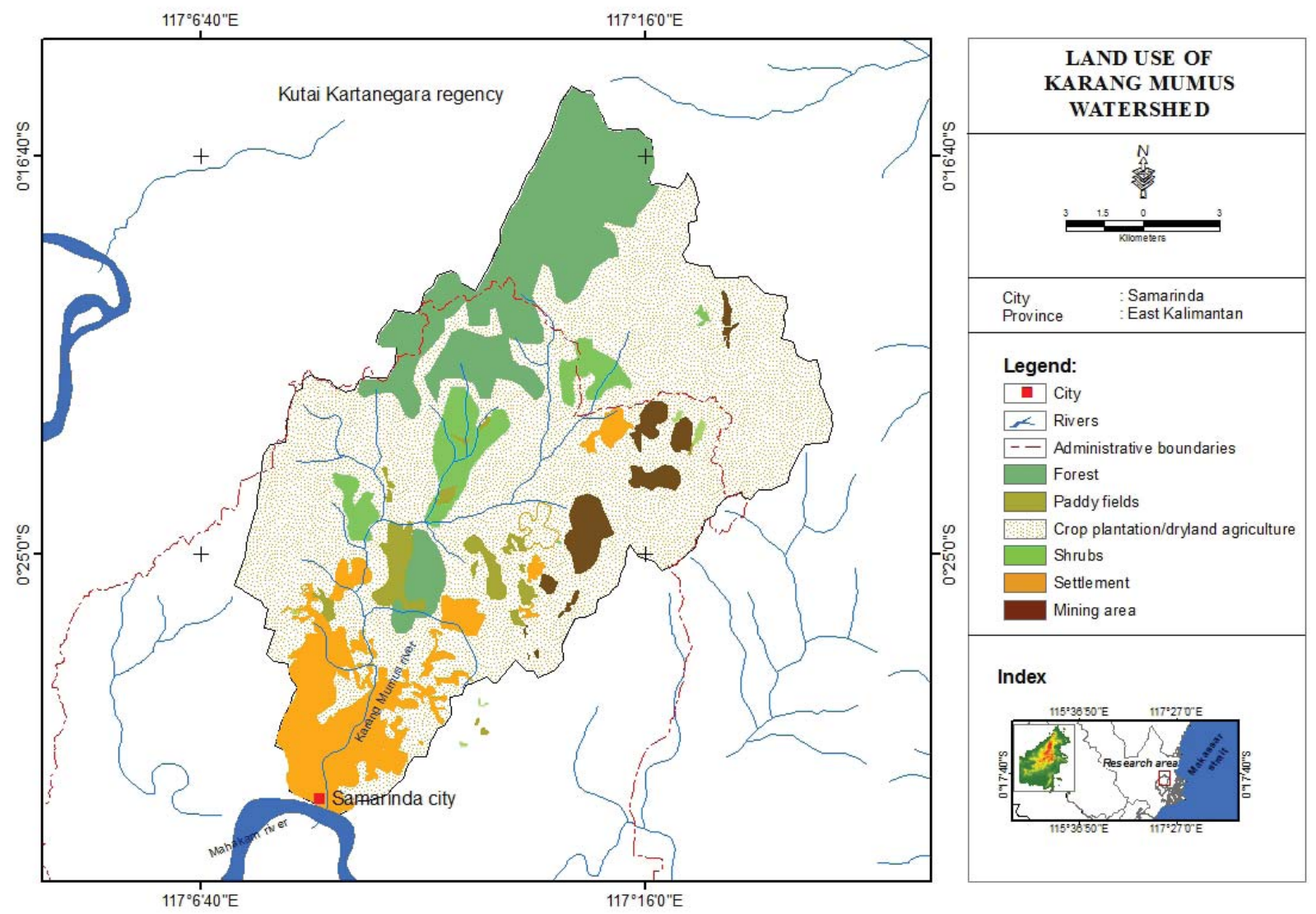

Figure 5. Location and land use map of study area
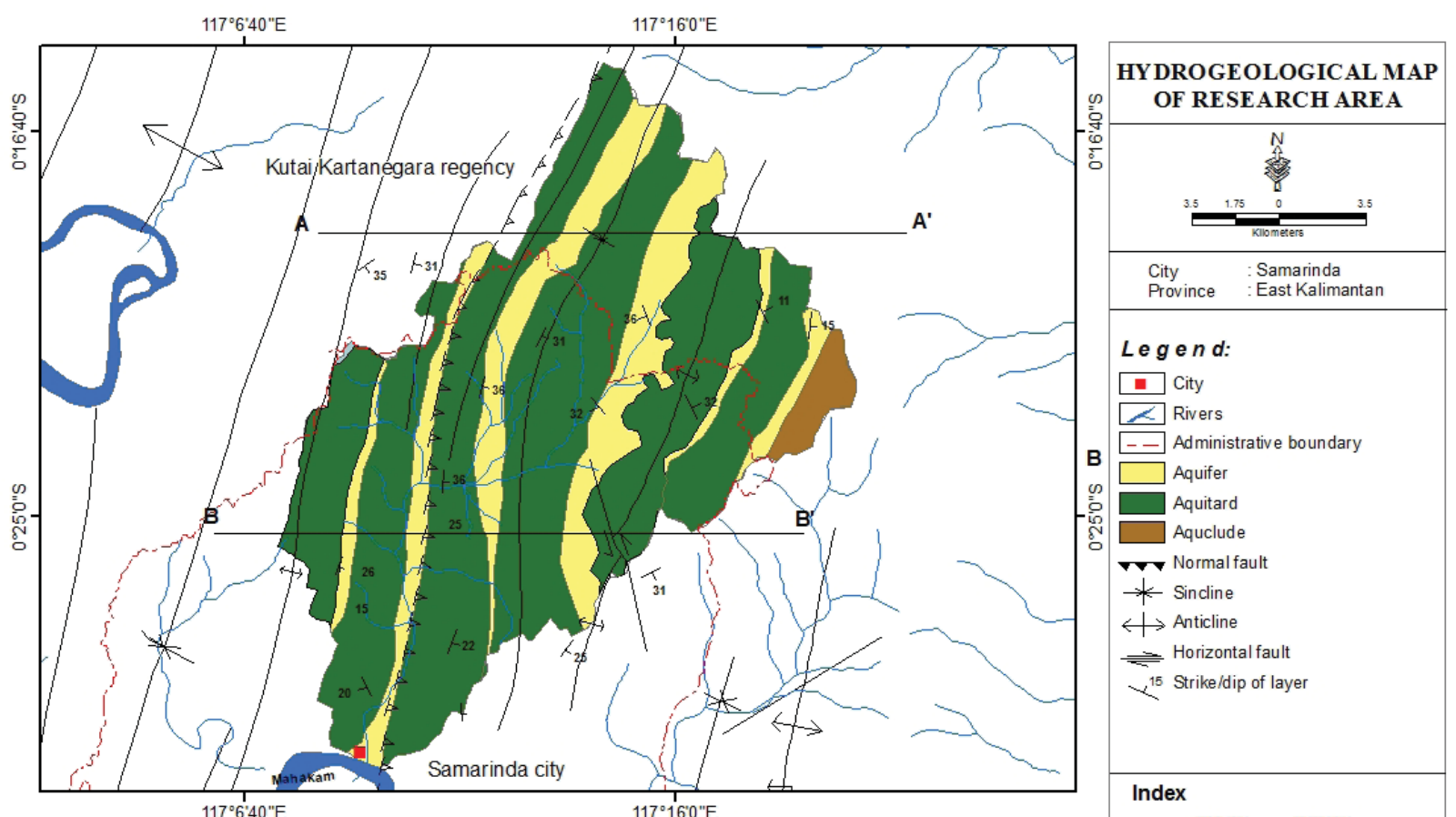

\section{Legend: \\ $\square$ City
$\measuredangle$ Rivers \\ B -- Administrative boundary}

B $\square$ Aquifer

$\square$ Aquitard

: $\square$ Aquclude

Normal fault

$*$ Sincline

$\leftrightarrow$ Anticline

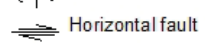

$\chi^{15}$ Strike/dip of layer

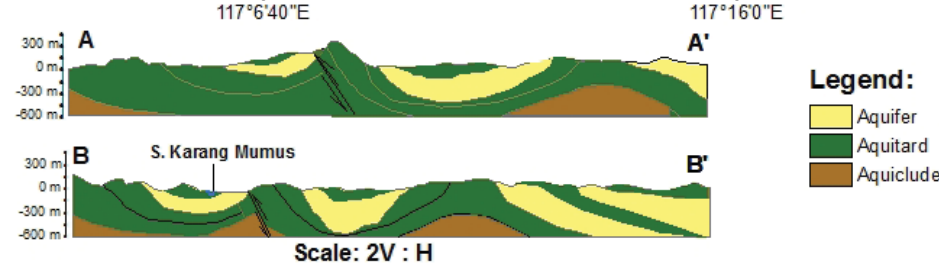

Index

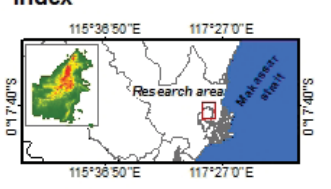

Figure 6. Location and hydrogeological map of study area 
Table 2. Groundwater recharge in study site.

\begin{tabular}{|c|c|c|}
\hline \multirow[t]{2}{*}{ Parameter } & $\begin{array}{c}\text { Catchment } \\
\text { area }\end{array}$ & \multirow[t]{2}{*}{ Unit } \\
\hline & Total & \\
\hline Precipitation $(\mathrm{P})$ & $2,670.4$ & $\mathrm{~mm}$ \\
\hline Real evapotranspiration $\left(\mathrm{ET}_{\mathrm{r}}\right)$ & 2,443 & $\mathrm{~mm}$ \\
\hline Surface runoff (Ro) & 77.6 & $\mathrm{~mm}$ \\
\hline Groundwater recharge (R) & 247.73 & $\mathrm{~mm}$ \\
\hline
\end{tabular}

Table 3. Resistivity of geoelectric measurement at location 1 (Balikpapan formation).

\begin{tabular}{ccccccc}
\hline \multicolumn{4}{c}{ Measurement } & \multicolumn{2}{c}{ Lithostratigraphy } \\
\hline Layer & $\begin{array}{c}\boldsymbol{\rho} \\
(\mathbf{o h m} . \mathbf{m})\end{array}$ & $\begin{array}{c}\text { H } \\
(\mathbf{m})\end{array}$ & $\begin{array}{c}\mathbf{D} \\
(\mathbf{m})\end{array}$ & $\begin{array}{c}\text { Elevation } \\
(\mathbf{m})\end{array}$ & Lithology & Symbols \\
\hline 1 & 501 & 1.25 & 0.85 & -0.75 & Soil & \\
2 & 2219 & 0.431 & 1.18 & -2.281 & Coarse grain & \\
3 & 344 & 5.3 & 6.41 & -6.5 & Siltstone & \\
4 & 3.7 & 1.70 & 8.11 & -8.108 & Sandstone & \\
5 & 265 & 1.76 & 9.47 & -9.1 & Siltstone & \\
6 & 19.9 & 12.9 & 22.7 & -22.65 & Sandstone & \\
\hline
\end{tabular}

The results generated from the application of the groundwater recharge computation method are presented in Table 2 . The groundwater recharge data are derived from secondary data analyzed by statistically (Kamiana, 2010), including the last 10 years' precipitation $(\mathrm{P})$ data obtained from Temindung Airport Samarinda (2006-2016); evapotranspiration $\left(\mathrm{ET}_{\mathrm{r}}\right)$ data obtained from the combination ofland use and precipitation; and surface runoff (R) data obtained from surface conditions, particularly land use and the physical properties of the soil/surface rock.

\subsection{Study Site Hydrogeology}

The lithology of the study site determines the hydrogeological conditions, which consist of the availability of water sources and the aquifer characteristics of the rock layers. Based on the classification developed by Mandel \& Shiftan (1981), Puradimaja (1993) and Irawan \& Puradimaja (2013), and modified in accordance with the geomorphological and geological typology of Indonesia, the study area is classified as a folded sedimentary aquifer system. Such a system results from folding structures, namely anticline structures stretching in a north-south direction. Based on the division of lithostratigraphic and stratigraphic units, the hydrostratigraphic unit of the study site is part of the hydrogeological unit of the folded sedimentary aquifer system (part of the Samarinda Anticlinorium).

The hydrogeological map in Figure 6 shows that the distribution of the aquifer lithology of the study site is determined by geological history, with tectonic conditions causing the deformation of the geological units. Deformation in the form of anticline folds has formed a folded sedimentary aquifer that leads to low groundwater potential at this site. In addition, rocks composed of and dominated by siltstone, sandstone clay and coal, which have semi-impermeable properties, relatively lower the groundwater potential. Assessment of the groundwater characteristics was based on observation at the location of the emergence of the artesis of the wellbore. The type of artesis found in the study area is fracture artesian springs, particularly at the intersection of sandstone and the siltstone layer. 
Table 4. Resistivity based on geoelectrical measurement at location 2 (Balikpapan formation).

\begin{tabular}{ccccccc}
\hline \multicolumn{4}{c}{ Measurement } & \multicolumn{2}{c}{ Lithostratigraphy } \\
\hline Layer & $\begin{array}{c}\boldsymbol{\rho} \\
(\mathbf{o h m} . \mathbf{m})\end{array}$ & $\begin{array}{c}\mathbf{H} \\
(\mathbf{m})\end{array}$ & $\begin{array}{c}\mathbf{D} \\
(\mathbf{m})\end{array}$ & $\begin{array}{c}\text { Elevation } \\
(\mathbf{m})\end{array}$ & Lithology & Symbols \\
\hline 1 & 1220 & 0.75 & 0.75 & -0.75 & Soil & \\
2 & 41442 & 0.442 & 1.19 & -1.092 & Coarse grain & \\
3 & 92.2 & 1.11 & 2.3 & -2.297 & Sandstone & \\
4 & 3677 & 2.48 & 4.77 & -4.773 & Claystone & \\
5 & 61.9 & 7.68 & 12.35 & -12.95 & Sandstone & \\
6 & 43.2 & 0.5 & 12.75 & -12.71 & Sandstone & \\
7 & 265 & 1.76 & 9.47 & -9.1 & Siltstone & \\
\hline
\end{tabular}

Table 5. Resistivity based on geoelectrical measurement at location 3 (Pulau Balang formation)

\begin{tabular}{ccccccc}
\hline \multicolumn{3}{c}{ Measurement } & \multicolumn{2}{c}{ Lithostratigraphy } \\
\hline \multirow{2}{*}{ Layer } & $\begin{array}{c}\boldsymbol{\rho} \\
(\mathbf{o h m} . \mathbf{m})\end{array}$ & $\begin{array}{c}\mathbf{H} \\
(\mathbf{m})\end{array}$ & $\begin{array}{c}\mathbf{D} \\
(\mathbf{m})\end{array}$ & $\begin{array}{c}\text { Elevation } \\
(\mathbf{m})\end{array}$ & Lithology & Symbols \\
\hline 1 & 1679 & 1.11 & 1.21 & 1.32 & Soil & \\
2 & 255 & 0.627 & 1.74 & -1.68 & Claystone \\
3 & 187 & 2.13 & 4.2 & -4.44 & Claystone \\
4 & 1817 & 3.17 & 7.9 & -7.47 & Coarse grain \\
5 & 205 & 2.32 & 9.5 & -9.82 & Claystone \\
6 & 936 & 3.08 & 12.8 & -12.76 & Claystone \\
7 & 26.4 & 11.4 & 24.6 & -24.15 & Sandstone & \\
\hline
\end{tabular}

Table 6. Resistivity based on geoelectrical measurement at location 4 (Pulau Balang formation)

\begin{tabular}{ccccccc}
\hline \multicolumn{3}{c}{ Measurement } & \multicolumn{2}{c}{ Lithostratigraphy } \\
\hline \multirow{2}{*}{ Layer } & $\begin{array}{c}\boldsymbol{\rho} \\
(\mathbf{o h m} . \mathbf{m})\end{array}$ & $\begin{array}{c}\mathbf{H} \\
(\mathbf{m})\end{array}$ & $\begin{array}{c}\mathbf{D} \\
(\mathbf{m})\end{array}$ & $\begin{array}{c}\text { Elevation } \\
(\mathbf{m})\end{array}$ & Lithology & Symbol \\
\hline 1 & 1007 & 1.41 & 1.39 & -1.4 & Soil & \\
2 & 3634 & 0.322 & 1.87 & 1.82 & Claystone \\
3 & 565 & 1.73 & 3.41 & -3.52 & Claystone \\
4 & 4836 & 24.4 & 27.8 & -27.79 & Coarse grain & \\
5 & 26.1 & 16 & 47.8 & -43.83 & Sandstone & \\
\hline
\end{tabular}

Table 7. Hydraulic conductivity on study site

\begin{tabular}{lllcl}
\hline & \multicolumn{1}{c}{ Lithology } & \multicolumn{1}{c}{ Layer } & \multicolumn{1}{c}{ K $\left(\mathrm{m} \mathrm{sec}^{-1}\right)$} & \multicolumn{1}{c}{ Formation } \\
\hline 1 & Sand - sandstone & Aquifer & $2.1 \times 10^{-4}-3.15 \times 10^{-4}$ & Balikpapan \\
2 & Clayey sandstone - siltstone & Aquitard & $2.2 \times 10^{-6}-6.4 \times 10^{-7}$ & Pulau Balang \\
3 & Claystone & Aquiclude & $2 \times 10^{-10}-1.2 \times 10^{-11}$ & Pulau Balang \\
\hline
\end{tabular}

\subsection{Aquifer Type}

The geoelectrical measurements in the study site produced the data presented in Tables 3,4 and 5 . Table 3 shows that the first layer has a resistivity $(\rho)$ of 501 , a thickness $(h)$ of $1.25 \mathrm{~m}$ and a depth $(d)$ of $0.85 \mathrm{~m}$. It is concluded that there is a soil layer on the surface with a thickness of $1.25 \mathrm{~m}$, at a depth of $0-2.1 \mathrm{~m}$. In the second layer, the resistivity of 2219 is dominated by sandstone and similar rock found at a depth of $2.281 \mathrm{~m}$. Layers with resistivity less than 20 ohm.m can be interpreted as claystone layers, while those with resistivity higher than 60 ohm.m are interpreted as relatively hard rock. From the results of the quantitative analysis, two layers at location 1 were presumed to have 
the potential for groundwater aquifers, namely layers 4 and 6. Layer 6 was estimated to have considerable groundwater potential in the form of confined groundwater since it is bounded by an impermeable layer of interlaminated siltstone.

The thickness of the layers has a resistivity of $19.9 \mathrm{ohm} . \mathrm{m}$. With reference to Table 4 , the resistivity of layer 1 was 1220 and the layer thickness was $0.75 \mathrm{~m}$, at a depth of $0.75 \mathrm{~m}$. It is a soil layer with a thickness of $0.75 \mathrm{~m}$ at a depth in the range of between $0-0.75 \mathrm{~m}$. In layer 2 , the resistivity was $41442 \mathrm{ohm} . \mathrm{m}$, which is interpreted as being a sandstone layer at a depth of 1.092. Based on the quantitative analysis of the values of location 2 in Table 4, three layers are predicted to have groundwater potential, namely layers 3, 5 and 6. Meanwhile, layer 5 and layer 6 have considerable groundwater potential in the form of confined water, since these layers are bounded by two layers of claystone. The resistivity of the layers is 43.2 and 61.9 ohm.m, with thicknesses of $0.5 \mathrm{~m}$ and $7.68 \mathrm{~m}$, respectively. Table 5 quantitatively presents the values from location 3 , which indicate that one aquifer layer, layer 7 , is predicted to have potential for groundwater in the form of confined groundwater due to it being bounded by two impermeable layers. The resistivity of the layer is $26.4 \mathrm{ohm} . \mathrm{m}$, with a thickness of approximately $11.4 \mathrm{~m}$, at a depth of $24.6 \mathrm{~m}$. Table 6 quantitatively shows that, in accordance with the values of the points at location 4 , one layer, layer 5 , is expected to have considerable groundwater potential in the form of confined groundwater as it is bounded by two impermeable layers. The resistivity of this layer is $26.1 \mathrm{ohm}$. m, at a depth of $47.8 \mathrm{~m}$.

Aquifer tests were also carried out by using a pumping test and the slug test method. These tests are intended to determine aquifer characteristics, including hydraulic conductivity. The variation in this conductivity is predominantly in accordance with the unit of geological rock or the aquifer type of each formation. Pumping and slug tests were conducted in several locations that represent the study site, based on geological and aquifer units scattered laterally from north to south.
The results of the aquifer tests can be seen in Table 7.

\subsection{Discussion}

The results of the geoelectrical interpretation and analysis, the interpretation of the geological data and the aquifer tests indicate that the aquifer layer functions as a water-bearing layer, and is constrained and covered by a sealing layer at the top of relatively semi-impermeable rock, i.e. clayey sandstone. The presence of sandstone, with the majority of the inserts being very compact and old as a result of the tectonic process which formed this layer, might have low aquifer potential. Most of the study site is in the form of an aquitard layer, which spreads evenly lining along the anticline.

The results of the calculation of resistivity in the Balikpapan and Pulau Balang formations can explain in which position (depth) of aquifer layer are following the slope of sedimentary rock layers. Analysis of the relationship between groundwater and surface water (river water) indicates a good relationship in quantity as well as the quality, with regard to the quantity of groundwater supply. This is indicated by the direction of water flow into the Karang Mumus River, flowing south-west and eventually into the Mahakam River, while the direction of groundwater flow relatively follows the rock layers affected by the anticline structure. However, geoelectrical data from the Bebuluh and Kampungbaru formations could not be obtained due to field constraints and the fact that the layers are dominated by subsurface layers.

The depth of the semi-confined aquifers vary, but those that have potential as productive aquifers are grouped into two types, namely: (1) aquifers with a depth of less than $30 \mathrm{~m}$; and (2) aquifers with a depth of more than $30 \mathrm{~m}$. The first group is located in the upper layer, scattered around and stretching from north to south on the Balikpapan formation, while the second group is located in the north and south of the sub-surface of the study site, precisely under the Pulau Balang formation. The thickness of the aquifers are relatively high in 
the middle of the fold, with a wide distribution, thus providing a good groundwater reserve. However, this situation is greatly affected by the quantity of groundwater recharge in the aquifer and the land use of the study site.

The results of Visual Modflow modeling indicate that the hydraulic head values of the wellbores at the study site vary, with a maximum height of $86 \mathrm{~m}$ asl and a minimum of $78 \mathrm{~m}$ asl. High hydraulic heads are situated in the groundwater divide boundary in the form of the northern hills, while the low hydraulic heads are adjacent to the Karang Mumus River. The equipotential of the hydraulic heads is relatively distributed from high elevations in the north, south, west and east, towards low elevations in the central area of the Karang Mumus River. Such a distribution pattern in the upper aquifer layer indicates that the hydraulic head equipotential is relatively lower and denser when reaching the river network, i.e. the Karang Mumus River. This causes the groundwater of the upper aquifer layer to flow into rivers with low hydraulic heads and limited quantity of water. Hence, it can be verified that the groundwater serves as a gaining stream or effluent.

\section{Conclusion}

The study site is included in the typology of the folded sedimentary aquifer system and classified as a semi-confined aquifer. Due to the anticline structure stretching from the northeast to the southwest, and the results of the geoelectrical test, it can be concluded that aquifer depth is below $30 \mathrm{~m}$ in the Balikpapan formation fromthe north to the south, while the aquifer depth is above $30 \mathrm{~m}$ under the surface of the Pulau Balang formation. Interaction with the rock formations of the study site consists of three layers, dominated by an aquitard layer, aquifer layer and aquiclude layer, respectively. The Karang Mumus watershed can be divided intothreehydrogeological layers:(1) an aquitard layer at the top, with a hydraulic conductivity of $4.3 \times 10^{-6} \mathrm{~m} / \mathrm{sec}$, dominated by siltstone; (2) an aquifer layer in the middle, with a hydraulic conductivity of $2.6 \times 10^{-4} \mathrm{~m} / \mathrm{sec}$, dominated by sand and sandstone; (3) and an aquiclude layer at the bottom, with a hydraulic conductivity of $1.6 \times 10^{-11} \mathrm{~m} / \mathrm{sec}$, and dominated by claystone. Basically, the aquifer thickness in the anticline provides good groundwater reserves, but it is affected by the quantity of groundwater recharge of $247.73 \mathrm{~mm}$, which is closely linked with land use.

\section{Acknowledgments}

The authors would like to thank the Directorate for Research and Community Service, the Directorate General for Research and Community Service Development, and the Ministry of Research, Technology and Higher Education, who provided financial support. Gratitude is also expressed to Mr. Hasyim as the facilitator and discussion partner, and the Survey and Geology Laboratory, Faculty of Engineering, University Mulawarman.

\section{References}

Adriyani, N. (2014). Geologi dan Sumberdaya pada Lapisan Batubara Seam A5 Daerah Merandai Kotamadya Samarinda Kalimantan Timur (PhD Thesis). UPN"VETERAN"YOGYAKARTA.

Albhaisi, M., Brendonck, L. and Batelaan, O. (2013). Predicted Impact of Land Use Change on Groundwater recharge of Upper Berg Catchment, South Africa, Water South Africa Journal. Vol. 39, No. 2. pp. 211-220.

Ali, M.N., Za'ari, Supoyo. (2003). “Eksplorasi Sumber Daya Mineral Air Bawah Tanah: Studi Kasus di Kawasan Industri Pasuruan Jawa Timur", Proceeding of Joint Convention The $32^{\text {nd }}$ IAGI dan The $28^{\text {th }}$ HAGI Annual Convention and Exhibition.

Arsyad, S. (1989). Konservasi Tanah dan Air, IPB Press, Bogor, pp. 85-86.

Asdak, C. (1995). Hidrologi dan Pengelolaan Daerah Aliran Sungai, Gadjah Mada University Press, Yogyakarta, pp. 154-210.

Azhar, Handayani, G., (2004). “Penerapan Metode Geolistrik Konfigurasi Schlumberger untuk 
Penentuan Tahanan Jenis Batubara'. Jurnal Natur Indonesia 6 (2), pp. 122-126.

Cholil, M. (2004). Unconfined Groundwater Quality based on the Settlement Unit in Surakarta City. Forum Geografi. 11(1). doi:10.23917/ forgeo.v11i1.495.

Cibaj, I., Lambert, B., Zaugg, P., Ashari, U., Dal, J.-A., \& Imbert, P. (2014). Stratigraphic Stacking Patterns of the Mahakam Area, Lower Kutei Basin, East Kalimantan, Indonesia.

Dinas Kesehatan Provinsi Kalimantan Timur. (2012). Profil Kesehatan Provinsi Kalimantan Timur 2012,

Hammer, M.J. and Mac Kitchen, K.A. (1981). Hydrology and Quality of Water Resources. New York: John Wiley \& Sons Ltd.

Healy, R.W. and Cook P.G. (2002). Using Groundwater Levels to Estimate Recharge. Hydrogeology Journal, Vol. 10, No. 1, pp. 91-107.

Irawan, D.E. and Puradimaja, D.J. (2013). Lembar Kerja Hidrogeologi Umum, Kelompok Keahlian Geologi Terapan Fakultas Ilmu dan Teknologi Kebumian Institut Teknologi Bandung.

Kamiana, I. (2010). Teknik Perhitungan Debit Rencana Bangunan Air, Graha Ilmu, Yogyakarta, pp. 28-30, 203.

Lerner, D.N. (1990). Groundwater recharge in Urban Areas, Hydrological Processes and Water Management in Urban Area, Proceedings of the Duisberg Symposium, April 1990, IAHS Publ., No. 198.

Lerner, D.D. (2002). Identifying and Quality Urban Recharge: A Review. Hydrogeology Journal, Vol. 10, pp. $143-152$.

Mandel, S. and Shiftan, Z.L. (1981). Groundwater Resources: Investigation and Development. Academic Press Inc.

Nalendra Jati, S. (2014). Kendali Geologi terhadap Geometri Lapisan Batubara di Antiklinorium Samarinda (PhD Thesis). UPN "VETERAN" YOGYAKARTA.

Puradimaja, D.J. (1993). Penyusunan Tipologi Paket Penelitian Sumber Daya Air, LAPI ITBDepartemen Transmigrasi, Bandung.

Seiler, K.P. and Gat, J.R. (2007). Groundwater Recharge from Run-Off, Infiltration and Percolation. Springer.

Supriatna, S. Sukardi, R, and R. Rustandi. (1995). Peta Geologi Bersistem, Lembar Samarinda, Kalimantan sekala 1:250.000, Pusat Penelitian dan Pengembangan Geologi Bandung.

Telford, W.M., Gerald, L.P., and Sheriff, R.E. (1990). Applied Geophysics Second Edition. Cambridge University Press.

Van Bemmelen, R.W. (1949). The Geology of Indonesia, Government Printing Office, The Hague, Netherlands, pp. 328-360.

Yangxiao, Z. and Wenpeng, L., (2011). A review of regional groundwater flow modeling. Geoscience Frontiers, Vol. 2, Issue 2, April 2011, pp. 205-214. 